\title{
PELATIHAN PEMETAAN POTENSI DASAR DAN PENGELOMPOKAN SERTA PEMBEKALAN LIFE SKILL PADA PKBM INSAN KARYA
}

\author{
Feb Amni Hayati *, Endang Sugiarti, Ana Septia Rahman \\ Dosen Fakultas Ekonomi. Universitas Pamulang \\ Email*: amni feb@yahoo.com
}

\begin{abstract}
ABSTRAK
Tulisan ini bertujuan untuk mengetahui tingkat penguasaan manajemen pengembangan potensi dasar dan pengelompokan serta pembekalan life skill dapat di terapkan bagi warga belajar PKBM Insan Karya melalui pelatihan yang dilaksanakan oleh Dosen dan Mahasiswa Universitas Pamulang.

Teknik pendekatan dilakukan dengan metode seminar dan simulasi secara oral dan menggunakan perangkat komputer.

Hasil kegiatan dapat meningkatkan kemampuan peserta untuk mengidentifikasi, memanfaatkan potensi yang ada pada dirinya dengan penguasaan ilmu pengetahuan dan teknologi.
\end{abstract}

\section{Kata Kunci : Sumber Daya Manusia, Potensi Dasar, Life Skill}

\section{PENDAHULUAN}

Pengabdian kepada masyarakat merupakan pelaksanaan pengamalan ilmu pengetahuan, teknologi dan seni budaya langsung pada masyarakat secara kelembagaan melalui metodologi ilmiah sebagai penyebaran Tri Dharma Perguruan Tinggi serta tanggung jawab yang luhur dalam usaha mengembangkan kemampuan masyarakat, sehingga dapat mempercepat laju pertumbuhan tercapainya tujuan pembangunan nasional.

Kegiatan pengabdian masyarakat merupakan salah satu Tri Dharma Perguruan Tinggi Selain Pendidikan dan Penelitian, sesuai undang-Undang RI Nomor 20 Tahun 2003 tentang Sistem Pendidikan Nasional, pada Pasal 20 ayat 2 dinyatakan: "Perguruan Tinggi berkewajiban menyelenggarakan pendidikan, penelitian dan pengabdian masyarakat". Pada Pasal 24 ayat 2 disebutkan:"Perguruan tinggi memiliki otonomi untuk mengelola sendiri lembaganya sebagai pusat penyelenggaraan pendidikan tinggi, penelitian ilmiah, dan pengabdian masyarakat". 
Program pengabdian kepada masyarakat merupakan salah satu program yang wajib dilaksanakan, baik oleh dosen maupun oleh mahasiswa, dengan berlandaskan pada prinsip-prinsip: kompetensi akademik, jiwa kewirausahaan (entrepreneurship), dan profesional, sehingga dapat menghasilkan program pengabdian kepada masyarakat yang bermutu, relevan, dan sinergis dalam meningkatkan pemberdayaan masyarakat.

Pendidikan merupakan salah satu faktor yang sangat penting bagi upaya kemajuan suatu bangsa. Sebab pendidikan bertugas untuk meningkatkan sumber daya manusia yang memiliki pengetahuan, melatih keterampilan serta menanamkan sikap dan prilaku yang baik dalam kehidupan berbangsa dan bernegara.

Pendidikan juga merupakan kebutuhan dasar (basic need) dalam kehidupan manusia. Kebutuhan dasar ini sejatinya harus terpenuhi dalam rangka membebaskan manusia dari berbagai persoalan hidup yang melingkupinya, karena hakekatnya pendidikan adalah salah satu instrumen yang paling efektif untuk membebaskan manusia dari segala bentuk penindasan, kebodohan, kemiskinan dan ketertinggalan.

Tentu saja, merealisasikan fungsi pendidikan itu sendiri harus dilakukan melalui upaya peningkatan kualitas pendidikan yang terintegrasi dengan proses peningkatan kualitas sumber daya manusia itu sendiri. Menyadari pentingnya proses peningkatan kualitas sumber daya manusia, maka pemerintah bersama masyarakat telah dan terus berupaya mewujudkan amanat tersebut melalui berbagai usaha pembangunan pendidikan yang lebih berkualitas antara lain melalui pengembangan perbaikan mutu pendidikan dan pemerataan pendidikan.

PKBM Insan Karya melibatkan banyak komponen masyarakat untuk menjadi penguat organisasi, sebagai pengajar dan juga sukarelawan. PKBM Insan Karya bersama masyarakat ingin mewujudkan pendidikan nonformal gratis yang dapat merangkul masyarakat menengah ke bawah yang tidak mendapat akses pendidikan formal atas berbagai alasan atau pun anak putus sekolah karena kesempitan ekonomi.

PKBM Insan Karya digagas dalam rangka menyiapkan peserta didik berkualitas melalui pendidikan Anak usia dini, pendidikan kesetaraan, pendidikan keaksaraan dan berkelanjutan yang dilaksanakan secara efektif dengan mengkedepankan kualitas pembelajaran yang sistematis dan terpadu.

Perkembangan ilmu pengetahuan dan teknologi saat ini menuntut sumber daya manusia mempunyai kemampuan penguasaan ilmu pengetahuan dan teknologi serta kecakapan hidup dalam pelatihan ini diharapkan warga belajar dapat meningkatkan kecakapan hidup sesuai dengan potensi yang dimilikinya Untuk mewujudkan hal tersebut, maka kami melakukan Pengabdian kepada masyarakat 
khususnya warga belajar PKBM Insan Karya dengan melaksanakan beberapa program pelatihan dan pengembangan diri yang dipandang sesuai dan bermanfaat bagi masyarakat di daerah tersebut.

Sasaran kegiatan pengabdian kepada masyarakat (pkm) ini adalah dengan mengajak warga belajar pkbm insan karya dan mahasiswa universitas pamulang untuk mengikuti Pelatihan Pemetaan Potensi Dasar Dan Pengelompokan Serta Pembekalan Life Skill Pada Pkbm Insan Karya.

\section{RUMUSAN MASALAH}

Berdasarkan latar belakang diatas dapat dirumuskan permasalahan sebagai berikut : Bagaimana tingkat penguasaan manajemen pengembangan potensi dasar dan pengelompokan serta pembekalan life skill dapat di terapkan bagi warga belajar PKBM Insan Karya melalui pelatihan yang dilaksanakan oleh Dosen dan Mahasiswa Universitas Pamulang?

\section{TUJUAN}

Tujuan yang ingin dicapai dalam kegiatan ini adalah : Untuk mengetahui tingkat penguasaan manajemen pengembangan potensi dasar dan pengelompokan serta pembekalan life skill dapat di terapkan bagi warga belajar PKBM Insan Karya melalui pelatihan yang dilaksanakan oleh Dosen dan Mahasiswa Universitas Pamulang

\section{KEGIATAN}

Sasaran dari program in Pengabdian Masyarakat yang akan kami lakukan ini adalah warga belajar PKBM Insan Karya. Jln. Haji Saleh, No. 42.RT. 05.RW.02, Benda Baru, Pamulang, Tangerang selatan.14516, pkbminsankarya.blogspot.co.id.

Jumlah peserta pelatihan kurang lebih 50 orang , meliputi warga belajar, program paket A, program paket B, program paket C, dan Program Keaksaraan.

Adapun pelaksanan dari kegiatan adalah sebagai berikut:

Hari

: Minggu s/d Rabu

Tanggal/Bulan

: 12 s/d 13 November 2017

Waktu

: Pukul 09.00 - 14.00 WIB

Tempat

: PKBM Insan Karya. Jln. Haji Saleh, No. 42.RT. 05.RW.

02, Benda Baru, Pamulang.Tangerang selatan. 14516 


\section{APLIKASI}

Mengawali uraian definisi atau pengertian manajemen sumber daya manusia menurut para ahli, patut dipahami bahwa faktor manusia sangat diperlukan dalam suatu organisasi sehingga muncul suatu ilmu manajamen yang mempelajari permasalahan ketenagakerjaan atau kepegawaian yang disebut dengan Manajemen Sumber Daya Manusia (MSDM).

Manajemen sumber daya manusia (human resources management) adalah pendayagunaan, pengembangan, penilaian, pemberian balas jasa, dan pengelolaan individu anggota organisasi atau kelompok pekerja (Simamora, $2006: 3$ ).

Manajemen sumber daya manusia didefinisikan sebagai suatu perencanaan pengorganisasian, pelaksanaan, dan pengawasan terhadap pengadaan, pengembangan, pemberian balas jasa, pengintegrasian, pemeliharaan, dan pemisahan tenaga kerja dalam rangka mencapai tujuan organisasi, Manajemen sumber daya manusia merupakan suatu perencanaan, pengorganisasian, pengkoordinasian, pelaksanaan dan pengawasan terhadap pengadaan, pengembangan, pemberian balas jasa, pengintegrasian, pemeliharaan dan pemisahan tenaga kerja dalam rangka mencapai tujuan organisasi (Mangkunegara, 2015:2)

Manajemen sumber daya manusia adalah penarikan, seleksi, pengembangan, pemeliharaan, dan penggunaan sumber daya manusia untuk mencapai titik tujuantujuan individu maupun organisasi (Handoko, 2012:4)

Manajemen sumber daya manusia adalah ilmu dan seni mengatur hubungan dan peranan tenaga kerja agar efektif dan efisien membantu terwujudnya tujuan perusahaan, karyawan dan masyarakat, Pengertian manajemen sumber daya manusia yakni ilmu dan seni mengatur hubungan dan peranan tenaga kerja agar efektif dan efisien membantu terwujudnya tujuan perusahaan, karyawan, dan masyarakat (Hasibuan, 2015:10)

Dari definisi atau pengertian manajemen sumber daya manusia menurut para ahli di atas, maka dapat disimpulkan bahwa manajemen sumber daya manusia merupakan bagian dari manajemen keorganisasian yang menekankan pada unsur SDM dan sudah menjadi tugas manajemen sumber daya manusia untuk mengelola unsur manusia secara baik agar diperoleh tenaga kerja yang tepat sesuai pekerjaannya, sehingga mampu bekerja optimal demi tercapainya tujuan perusahaan atau organisasi.

Potensi diri merupakan kemampuan, kekuatan, baik yang belum terwujud maupun yang telah terwujud, yang dimiliki seseorang, tetapi belum sepenuhnya terlihat atau dipergunakan secara maksimal oleh seseorang. 
Secara umum, potensi dapat diklasifikasikan sebagai berikut :

1. Kemampuan dasar, seperti tingkat intelegensi, kemampuan abstraksi, logika dan daya tangkap.

2. Etos kerja, seperti ketekunan, ketelitian, efisiensi kerja dan daya tahan terhadap tekanan.

3. Kepribadian, yaitu pola menyeluruh semua kemampuan, perbuatan, serta kebiasaan seseorang, baik jasmaniah, rohaniah, emosional maupun sosial yang ditata dalam cara khas di bawah aneka pengaruh luar.

Menurut "Howard Gardner", potensi yang terpenting adalah intelegensi, yaitu sebagai berikut:

1. Intelegensi linguistik, intelegensi yang menggunakan dan mengolah katakata, baik lisan maupun tulisan, secara efektif. Intelegensi ini antara lain dimiliki oleh para sastrawan, editor, dan jurnalis.

2. Intelegensi matematis-logis, kemampuan yang lebih berkaitan dengan penggunaan bilangan pada kepekaan pola logika dan perhitungan.

3. Intelegensi ruang, kemampuan yang berkenaan dengan kepekaan mengenal bentuk dan benda secara tepat serta kemampuan menangkap dunia visual secara cepat. Kemampuan ini biasanya dimiliki oleh para arsitek, dekorator dan pemburu.

4. Intelegensi kinestetik-badani, kemampuan menggunakan gerak tubuh untuk mengekspresikan gagasan dan perasaan. Kemampuan ini dimiliki oleh aktor, penari, pemahat, atlet dan ahli bedah.

5. Intelegensi musikal, kemampuan untuk mengembangkan, mengekspresikan dan menikmati bentuk-bentuk musik dan suara. Kemampuan ini terdapat pada pencipta lagu dan penyanyi.

6. Intelegensi interpersonal, kemampuan seseorang untuk mengerti dan menjadi peka terhadap perasaan, motivasi, dan watak temperamen orang lain seperti yang dimiliki oleh seseorang motivator dan fasilitator.

7. Intelegensi intrapersonal, kemampuan seseorang dalam mengenali dirinya sendiri. Kemampuan ini berkaitan dengan kemampuan berefleksi (merenung) dan keseimbangan diri.

8. Intelegensi naturalis, kemampuan beradaptasi dengan lingkungan alam

Sementara sebagaimana dijelaskan dalam Kurikulum 2004, kecakapan hidup adalah "Kecakapan yang dimiliki seseorang untuk mampu memecahkan permasalahan hidup secara wajar dan menjalani kehidupan secara bermartabat 
tanpa merasa tertekan, kemudian secara proaktif mencari serta menemukan solusi, sehingga akhirnya mampu mengatasinya".

Berdasarkan pengertian di atas, kecakapan hidup (life skills) merupakan kecakapan untuk memecahkan masalah secara inovatif dengan menggunakan fakta, konsep, prinsip atau prosedur yang telah dipelajari. Pemecahan masalah tersebut dapat berupa proses maupun produk yang bermanfaat untuk mempertahankan, meningkatkan, atau memperbaharui hidup dan kehidupan siswa.

Kecakapan hidup tersebut diharapkan dapat dicapai melalui berbagai pengalaman belajar siswa.Dari berbagai pengalaman mempelajari berbagai mata pelajaran, diharapkan siswa memperoleh hasil sampingan yang positif berupa upaya memanfaatkan pengetahuan, konsep, prinsip dan prosedur untuk memecahkan masalah baru dalam bentuk kecakapan hidup.Di samping itu, kecakapan hidup tersebut hendaknya diupayakan pencapaiannya dengan mengintegrasikannya pada topik dan pengalaman belajar yang relevan (Depdiknas, 2003).

Dengan demikian, life skills memiliki makna yang lebih luas dari kecakapan kerja tertentu (vocational skills).Life skills lebih tepat diartikan sebagai kecakapan hidup. Pengertian kecakapan hidup di sini, tidak semata-mata berarti memiliki kemampuan tertentu saja, namun ia harus memiliki kompetensi dasar pendukungnya, seperti membaca, menulis, menghitung, merumuskan dan memecahkan masalah, mengelola sumber daya, bekerja dalam tim atau kelompok, terus belajar di tempat bekerja, mempergunakan teknologi, dan lain sebagainya.

Life skills (kecakapan hidup) menunjuk pada berbagai ragam kemampuan seseorang untuk menempuh kehidupan dengan sukses, bahagia dan secara bermartabat di dalam masyarakat. Life skills merupakan kemampuan sepanjang hayat, kepemilikan kemampuan berpikir yang kompleks, kemampuan komunikasi secara efektif, kemampuan membangun kerjasama, melaksanakan peranan sebagai warga negara yang bertanggungjawab, memiliki kesiapan serta kecakapan untuk bekerja, memiliki karakter dan etika untuk terjun ke dunia kerja (Depdiknas, 2003).

Berdasarkan pengertian life skills sebagaimana diuraikan di atas, pendidikan kecakapan hidup dapat difahami sebagai usaha untuk membantu dan membimbing aktualisasi potensi peserta didik untuk mencapai sejumlah kompetensi, baik berupa pengetahuan, keterampilan, sikap dan nilai yang mengarah pada permasalahan hidup, menjalani kehidupan secara mandiri dan bermartabat, serta proaktif dalam mengatasi masalah.

Pendidikan kecakapan hidup menurut Tim BBE Depdiknas (2002) pendidikan kecakapan hidup (Life Skills Education) merupakan proses pendidikan yang mengarah pada pembekalan kecakapan seseorang, untuk mampu dan berani 
menghadapi problema hidup dan kehidupan secara wajar, tanpa merasa tertekan, kemudian secara proaktif dan kreatif mencari solusinya, sehingga akhirnya mampu mengatasi problema tersebut.

Penjelasan pasal 26 ayat 3 UU No. 20 Tahun 2003 tentang Sistem Pendidikan Nasional menyebutkan bahwa pendidikan kecakapan hidup (life skills education) adalah "Pendidikan yang memberikan kecakapan personal, sosial, intelektual dan kecakapan vokasional untuk bekerja atau usaha mandiri".

\section{STRATEGI}

Dalam pelatihan pemetaan potensi dasar peserta diminta untuk mengisi bagan SWOT.Peserta diminta mengidentifikasi kekuatan dan kelemahan dirinya. Peluang dan hambatan yang di hadapi dari hasil identifikasi tersebut narasumber membimbing warga belajar PKBM Insan Karya untuk dapat mengetahui apa yang menjadi potensi dasar dirinya.

Dari identifikasi tersebut melalui teknik seminar, simulasi, pendekatan persuasif dan hypnoterapi peserta di berikan motivasi untuk meningkatkan kekuatan yang ada pada dirinya dan berusaha meminimalisir kekurangan yang ada pada dirinya. Juga dengan kekuatan tersebut diharapkan warga belajar PKBM Insan Karya dapat menangkap peluang yang ada dengan baik.

Perkembangan zaman mengharuskan sumber daya manusia menguasai ilmu pengetahuan dan teknologi dalam pelatihan ini, warga belajar PKBM Insan Karya di latih menguasai teknologi melalui pengaplikasian perangkat komputer, meliputi kemahiran ms. word, excel, publisher dan penguasaan jaringan internet.

\section{PENUTUP}

Pelaksanaan kegiatan pengabdian masyarakat oleh lembaga penelitian dan pengembangan masyarakat (LPPM) Universitas Pamulang yang dilakukan oleh dosen-dosen program studi manajemen telah berjalan dengan lancar dan mendapat sambutan hangat dari tempat pelaksanaan kegiatan ini yaitu Warga Belajar PKBM Insan Karya.

Harapan kami dengan pengabdian ini dapat membuka wawasan dari warga belajar PKBM Insan Karya yang kami berikanpelatihan dan praktek dalam bidang manajemen khususnya peningkatan potensi diri dan peningkatan life skill sekaligus bahan kajian dan masukan bagi masyarakat tersebut untuk dapat mengiplementasikannya dalam kehidupan sehari-hari, sehingga dapat membantu dan meningkatkan tingkat kehidupan dan kesejahteraan mereka pada masa yang akan datang. 


\section{DAFTAR REFERENSI}

Handoko.(2012). Manajemen Personalia Dan Sumber Daya Manusia.BPFE. Jogjakarta.

Hasibuan.(2015).Manajemen Sumber Daya Manusia (Edisi Revisi). Bumi Aksara. Jakarta.

Mangkunegara.(2015). Manajemen Sumber Daya Manusia. Remaja Rosda Karya. Bandung.

Simamora.(2006).Manajemen Sumber Daya Manusia.STIE YKPN .Yogyakarta. https://id.wikipedia.org/wiki/Potensi_diri http://www.definisi-pengertian.com/2015/05/definisi-pengertian-kecakapan-lifeskill.html 


\section{LAMPIRAN FOTO-FOTO KEGIATAN}
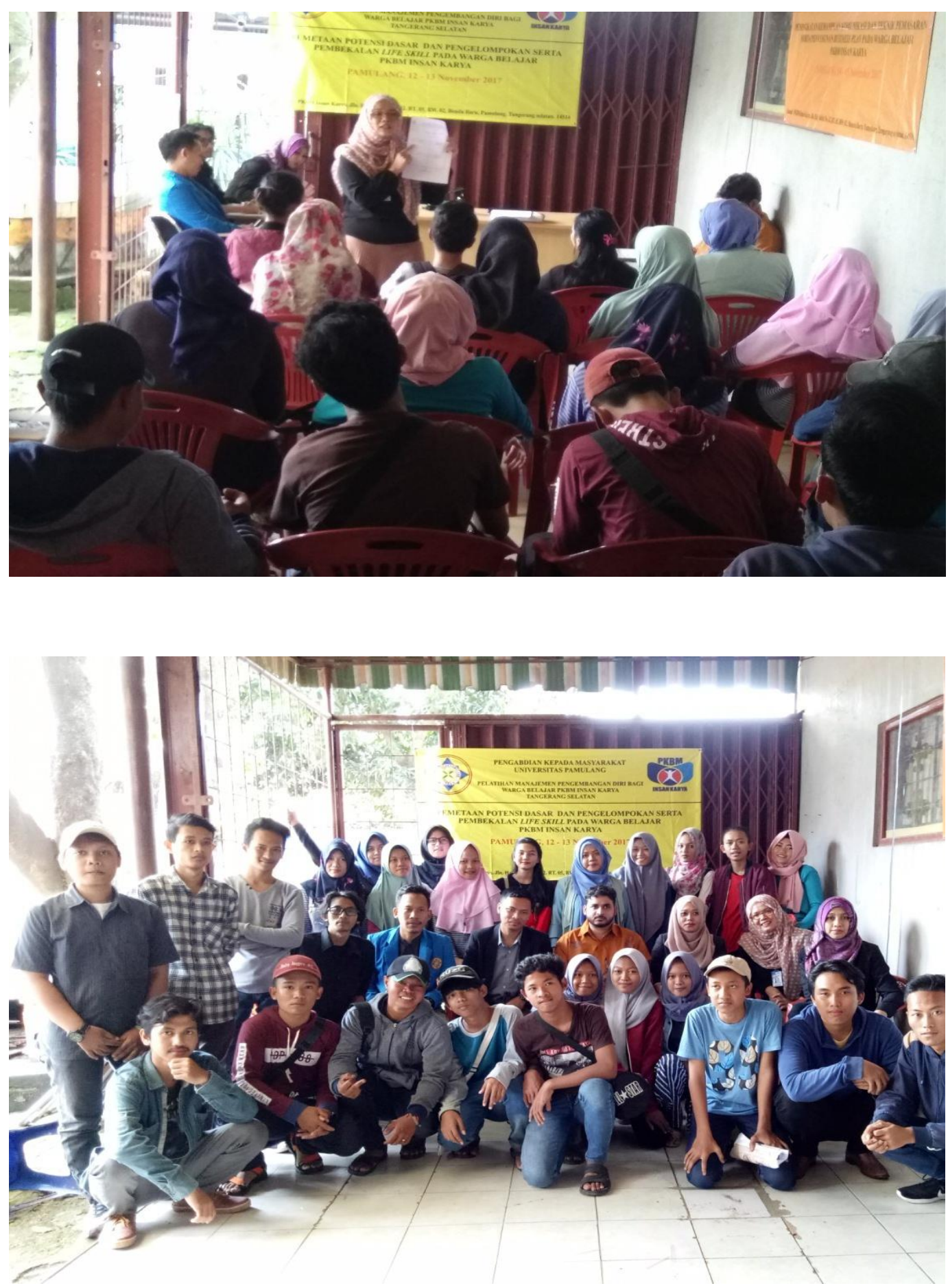